\author{
Julian Jezioro \\ ORCID: 0000-0001-7378-000X
}

Uniwersytet Wrocławski

https://doi.org/10.19195/1733-5779.32.12

\title{
Użytkowe wykorzystanie utworów w działalności przedsiębiorców - wybrane zagadnienia
}

\author{
JEL Classification: K15, K22, 034
}

Słowa kluczowe: prawo autorskie, utwór, użytkowe korzystanie z utworów, utwory użytkowe, przedmioty własności przemysłowej, programy komputerowe, utwory pracownicze, utwory będące zbiorem, utwory zbiorowe

Keywords: copyright, copyright work, utilitarian use of works, utility works, industrial property works, computer programs, employee works, works being collection, collective works

Abstrakt: Autor, w sposób dyskusyjny, prezentuje wybrane uregulowanie polskiego prawa autorskiego, które - w jego ocenie — jest wynikiem uwzględnienia różnic zdeterminowanych odmienną funkcją produkcji oraz „konsumpcji”, w odniesieniu do korzystania z przedmiotów własności intelektualnej. W przypadku korzystania przez przedsiębiorców określa je jako „użytkowe” i przeciwstawia korzystaniu „konsumpcyjnemu”, które wiąże się z zaspokajaniem potrzeb przez „docelowych” odbiorców produktów i usług, związanych z przedmiotami własności intelektualnej. W swoich rozważaniach nawiązuje do wcześniejszych publikacji wyników swoich badań, które były próbą uzasadnienia użyteczności posługiwania się w analizie prawnej innym określeniem — „utwory użytkowe”. Podstawową ogólną tezą opracowania jest stwierdzenie, że poza unormowaniem, dotyczącym utworów użytkowych, na podstawie uregulowania polskiego prawa autorskiego, da się dostrzec przepisy, które odmienności w uregulowaniu, w stosunku do zasad ogólnych, dotyczących wszystkich utworów, opierają na „użytkowym” korzystaniu z utworów. Przedmiotem analizy są w szczególności przepisy dotyczące utworów pracowniczych, utworów będących zbiorami oraz utworów zbiorowych. Praca zawiera też, w ograniczonym zakresie, odniesienia prowadzonej analizy do praktyki obrotu gospodarczego z perspektywy przedsiębiorców.

\section{Utility use of copyright works in business activity - selected issues}

Abstract: The author, in a controversial manner, presents the selected regulation of Polish copyright, which in his opinion is the result of taking into account differences determined by a different function of production and "consumption" in relation to the use of intellectual property objects. When used by entrepreneurs, he defines them as "utilitarian" and opposes their "consumer" use, 
which involves meeting the needs of "target" recipients of products and services related to intellectual property. In his considerations he refers to earlier publications of his research results, which were an attempt to justify the usefulness of using in legal analysis another term — "utilitarian works". The basic general thesis of the study is that, in addition to the regulation of utility works, based on the regulations of Polish copyright, one can see the provisions which differences in the regulation in relation to the general principles, applicable to all works, are based on the "utilitarian" use of works. The subjects of analysis are in particular the provisions on employee works, works being collections and collective works. The work also contains, to a limited extent, references of the conducted analysis to the practice of business trading from the entrepreneurs' perspective.

\section{Wprowadzenie}

W typowych sytuacjach korzystanie z przedmiotów własności intelektualnej przez przedsiębiorców oraz inne podmioty korzystające z działalności z tym związanej zdeterminowane jest odmienną funkcją czy też celem takiego korzystania. Cele takie wyznaczone są przez zobiektywizowane odmienne społeczno-gospodarcze funkcje produkcji oraz konsumpcji - stąd też korzystanie z przedmiotów własności intelektualnej (na przykład utworów) przez przedsiębiorców — na potrzeby prowadzonych tu rozważań — można wstępnie określić jako „użytkowe” i przeciwstawić je korzystaniu „konsumpcyjnemu”, które w praktyce społecznej wiąże się z zaspokajaniem potrzeb przez „docelowych” odbiorców produktów i usług związanych z przedmiotami własności intelektualnej. Pierwsze z nich polega na zaspokajaniu bezpośrednio typowych potrzeb, jakim służą utwory jako pewien przekaz informacyjny. Zasadniczo zmierzają do wytworzenia różnego rodzaju przedmiotów materialnych lub świadczenia usług, które są ustaleniem lub utrwaleniem tego „substratu” dobra intelektualnego, jakim jest na przykład utwór, artystyczne wykonanie, ale także projekty wynalazcze. Drugi rodzaj korzystania polega na swoistym odczytaniu informacji będącej przedmiotem własności intelektualnej (ogólnie jego recepcji) — za pomocą ustaleń i utrwaleń, będących wynikiem działalności przedsiębiorców — ma miejsce w świadomości odbiorcy (w typowych sytuacjach konsumenta w znaczeniu prawnym). Takie korzystanie w typowych sytuacjach służy wprawieniu ,docelowego" odbiorcy w zamierzony przez niego i twórcę stan emocjonalny lub poszerzenie zasobu informacji użytecznej ze względu na potrzeby osobiste albo praktykę społeczną (na przykład wykonywany zawód itp.). Zapewne w tej właśnie funkcji, czy też możliwości jej realizacji, zawiera się podstawa faktyczna istnienia weryfikowalnej wartości ekonomicznej, rodzaju „wartości dodanej”, ucieleśnionej w konkretnych przedmiotach własności intelektualnej. Należy dodać, że przedmioty własności intelektualnej są również „nośnikiem” wartości, trudnej do wyrażenia w sposób ekonomicznie weryfikowalny, ale także objętej ochroną prawną jako dobra osobiste. Jest oczywiste, że wzajemne przenikanie się tych wartości stwarza wiele problemów praktycznych w obrocie gospodarczym, dotyczącym dóbr intelektualnych, a także 
wpływa na uregulowanie prawne. Zarysowe i wybiórcze ich przedstawienie jest celem tego opracowania.

Objęcie ochroną prawną przedmiotów własności intelektualnej wynika z oczywistego uwarunkowania obiektywnego, jakim jest wyjątkowość występowania „zdolności” czy też umiejętności tworzenia tej kategorii dóbr. Zróżnicowanie ich ochrony (na przykład wyrażająca się występowaniem nie jednego rodzaju, ale wielu rodzajów przedmiotów własności intelektualnej) jest pochodną zróżnicowania potrzeb ,intelektualnych” oraz sposobów ich zaspokojenia. Wyraża się to w uregulowaniu prawnym, związanym ze stosunkami dotyczącymi przedmiotów własności intelektualnej, istnieniem, obok uregulowania ogólnego (dotyczącego przykładowo wszystkich rodzajów utworów), regulacji szczególnej, dotyczącej jedynie niektórych ich kategorii (na przykład programów komputerowych, baz danych itp.). Elementy takiej szczególnej regulacji poddane są w tym opracowaniu analizie.

Autor tego opracowania w innym miejscu (w publikacjach dotyczących utworów architektonicznych, dydaktycznych oraz z zakresu typografii wcześniej już opublikowanych ${ }^{1}$ lub złożonych do publikacji ${ }^{2}$ ) omawiał elementy unormowania prawa autorskiego, proponując posługiwanie się w analizie prawnej określeniem „,utwory użytkowe”. To opracowanie tylko częściowo wiąże się z wcześniej opublikowanymi rozważaniami. Jego podstawowym celem jest analiza zmierzająca do odpowiedzi inne pytanie - czy poza utworami użytkowymi, będącymi odrębnymi od innych, ale skonkretyzowanymi rodzajami utworów (autor tego opracowania wskazał wcześniej jako ich przykłady na programy komputerowe, utwory architektoniczne, dydaktyczne i typograficzne), na podstawie uregulowania polskiego prawa autorskiego da się dostrzec przepisy, które odmienności w uregulowaniu, w stosunku do zasad ogólnych (w znaczeniu dotyczących wszystkich utworów), opierają na wskazanym we wstępie „użytkowym” korzystaniu z utworów - a więc czy występują ogólne, dotyczące potencjalnie każdego utworu (zarówno użytkowych w ścisłym znaczeniu, jak i pozostałych) uregulowania, które są wynikiem uwzględnienia przez ustawodawcę, opisanego we wstępie „użytkowego" korzystania.

${ }^{1}$ Dotyczy to między innymi J. Jezioro, Sposób wyrażenia utworu architektonicznego jako element prawnego wyodrębnienia tego rodzaju utworów, [w:] Wybrane zagadnienia polskiego prawa prywatnego: księga pamiątkowa ku czci Doktora Józefa Kremisa i Doktora Jerzego Strzebinczyka, red. J. Jezioro, K. Zagrobelny, Wrocław 2019, s. 93-101; idem, Utwór jako element przedmiotu świadczenia w umowach o tzw. „świadczenia edukacyjne”, [w:] Ius est ars boni et aequi: księga pamiątkowa dedykowana Profesorowi Józefowi Frackowiakowi, red. A. Dańko-Roesler et al., Warszawa 2018, s. 383-394.

2 J. Jezioro, Utwory typograficzne - wybrane zagadnienia, złożono do wydania w ramach monografii, będącej zbiorową publikacją dla uczczenia profesora Andrzeja Kidyby [w druku]. 
Ze względu na cel i rozmiary tej publikacji prowadzone tu rozważania ograniczone zostaną do uregulowania prawa autorskiego ${ }^{3} \mathrm{i}$ jedynie wybranych aspektów tej regulacji, a tym samym analiza ta nie pretenduje do wyczerpującej prezentacji problematyki; ma też — w założeniu autorskim — charakter zarysowy i dyskusyjny. Analiza takiego uregulowania ma zarówno walor ogólnopoznawczy, jak i praktyczny, ściśle związany z uwarunkowaniami prawnymi działalności gospodarczej. Poza wykładnią przepisów może być pomocna przykładowo w kształtowaniu skonkretyzowanych stosunków prawnych, mających swoje źródło w umowach zawieranych w obrocie gospodarczym.

Wydaje się, że użytkowe korzystanie z utworów wpłynęło istotnie na aktualny kształt przepisów dotyczących utworów, będących wynikiem wykonania obowiązków ze stosunku pracy (zob. art. 12-15 oraz 74 ust. 3 PrAut), utworów będących zbiorami (na przykład baz danych, o których mowa w art. 3 PrAut), utworów zbiorowych (zob. art. 11 PrAut) oraz utworów audiowizualnych (zob. rozdział szósty PrAut). Ponadto tak rozumiana „użytkowość” może być powiązana z uregulowaniem wielu innych instytucji. Dotyczy to instytucji dozwolonego użytku (zob. art. 23 i n. PrAut), niektórych przepisów, dotyczących stosunków umownych z rozdziału piątego PrAut, regulujących przejście praw autorskich oraz korzystanie z utworów w ramach stosunków umownych (na przykład art. 49 PrAut). Cel i charakter tego opracowania zmusza do ograniczenia się jedynie do wybranych, w ocenie autora, istotnych z punktu widzenia przedsiębiorców korzystających z przedmiotów własności intelektualnej kwestii.

Podstawowym celem tego opracowania jest wskazanie i zarysowana analiza tej części regulacji prawnej, której odrębność wynika z uwzględnienia przez ustawodawcę użytkowego korzystania $\mathrm{z}$ utworów przez przedsiębiorców przy zastosowaniu koncepcji funkcjonalnej orientacji użytkowości. Prowadzona analiza dotyczy w szczególności unormowania przez PrAut stosunków związanych z utworami pracowniczymi, utworami będącymi zbiorami oraz utworami zbiorowymi.

\section{Utwory pracownicze}

Uregulowanie PrAut, dotyczące bezpośrednio utworów pracowniczych, jest literalnie stosunkowo zwarte i czytelne. Przepisy te wprowadzają pewne odmienności od zasad wynikających z uregulowania rozdziału piątego PrAut, a więc uregulowania dotyczącego zasadniczo umownego przejścia i korzystania z praw autorskich. Na podstawie orzecznictwa przyjmuje się, że omawiane tu przepisy dotyczące utworów pracowniczych mają, w stosunku do przepisów rozdziału

${ }^{3}$ Zasadniczo prowadzone tu rozważania dotyczą uregulowania ustawy z dnia 4 lutego 1994 roku o prawie autorskim i prawach pokrewnych, tekst jedn. Dz.U. z 2019 r. poz. 1231 ze zm. (dalej: PrAut). 
piątego PrAut, charakter lex specialis ${ }^{4}$. Opisowo rzecz ujmując - uregulowanie dotyczące utworów pracowniczych wprowadza zasady ogólne, dotyczące wszystkich utworów będących wynikiem wykonania obowiązków ze stosunku pracy oraz normuje w sposób szczególny trzy odrębne sytuacje szczególne.

Odrębności te dotyczą, w pierwszej kolejności, skutków stworzenia programu komputerowego w zakresie podmiotu pierwotnie nabywającego prawa wyłączne. Zgodnie z art. 74 ust. 3 PrAut wyjątkowo, wprost z ustawy, prawa autorskie nabywa nie autor, ale pracodawca twórcy utworów, będących programami komputerowymi - przy czym ustawa dopuszcza w tej kwestii odmienne porozumienie stron umowy o pracę. Ze względu na dyspozytywny charakter przepis ten nie wymaga szerszej analizy w aspektach praktycznych. Można jedynie wskazać, że dotyczy utworów, które są „,wzorcowe” dla kategorii „utwory użytkowe”, oraz jest zbieżne z analogicznymi rozwiązaniami dotyczącymi pracowniczych projektów wynalazczych (zob. art. 11 ust. 3 ustawy z dnia 30 czerwca 2000 roku Prawo własności przemysłowej) ${ }^{5}$. Prowadzi to do modyfikacji zasad wynikających z art. 12 PrAut, zgodnie z którymi pierwotnym nabywcą autorskich praw majątkowych do utworów pracowniczych innych niż programy komputerowe jest pracownik, a pracodawca nabywa je dopiero w chwili przyjęcia, a więc wyniku dodatkowego oświadczenia woli, które może być złożone także w sposób dorozumiany. Zgodnie $\mathrm{z}$ art. 13 PrAut, jeżeli pracodawca nie zawiadomi twórcy w terminie sześciu miesięcy od dostarczenia utworu o jego nieprzyjęciu lub uzależnieniu przyjęcia od dokonania określonych zmian w wyznaczonym w tym celu terminie, uważa się, że utwór został przyjęty bez zastrzeżeń, a strony mogą określić inny termin. Dla praktyki gospodarczej istotne wydaje się rozważenie umownego (poprzez wprowadzenie klauzuli umownej) usunięcia niepewności co do chwili przejścia na pracodawcę autorskich praw majątkowych. Sam skutek natomiast, polegający na przejściu autorskich praw majątkowych, wprost nie zależy od pracownika, skoro przyjęcie utworu zostało ukształtowane jako jednostronna czynność prawna.

Podkreślenia wymaga, że ogólnie, na podstawie PrAut, nabycie praw autorskich, zgodnie z treścią art. 12 w związku z art. 16 PrAut, nie obejmuje autorskich praw osobistych; mają one charakter niezbywalny. Podmiotem tych praw w sposób trwały pozostaje twórca (współtwórca) utworu stworzonego w ramach stosunku pracy, a ochrona w tym zakresie nie jest ograniczona czasowo i po śmierci autora wykonywanie (także ochrona) uprawnień osobistych powierzone zostało osobom wskazanym przez autora lub podmiotom, o których mowa w art. 78 ust. 2-4 PrAut. W praktyce gospodarczej może to wpływać na wykonywanie uprawnień majątkowych, nabytych przez pracodawcę. Wydaje się, że dotyczy to przede wszystkim kwestii komunikowania autorstwa utworu oraz wprowadzania do niego zmian, które nie prowadzą do powstania opracowania takiego utworu

\footnotetext{
4 Zob. wyrok SA w Poznaniu z dnia 20 lutego 2009 roku (I ACa 87/08, niepubl.).

5 Tekst jedn. Dz.U. z 2020, poz. 276 (dalej: PrWPrzem).
} 
w rozumieniu art. 2 PrAut. W przypadku programów komputerowych, a więc utworów „użytkowych” w przedstawionym na wstępie znaczeniu, ustawodawca zmodyfikował te zasady - ograniczył uprawnienia składające się na autorskie prawa osobiste tylko do prawa do autorstwa (zob. art. $77 \mathrm{w}$ związku z art. 16 PrAut) oraz uprawnienie do zmiany utworu uczynił elementem autorskich praw majątkowych, a więc praw zbywalnych (zob. art. 74 ust. 4 pkt 2 PrAut). Oznacza to możliwość nabycia prawa do zmiany programu jako elementu autorskich praw majątkowych do tego rodzaju utworów.

Oceniając zasadność przyjęcia przez PrAut opisanego powyżej unormowania z uwzględnieniem różnic w korzystaniu „użytkowym” i „konsumpcyjnym”, rozwiązanie przyjęte przez ustawodawcę należy uznać za trafne. Rysuje się to wyraźnie, jeśli w analizie posłużymy się — jako narzędziem weryfikacyjnym — koncepcją kierunku orientacji funkcjonalnej korzystania z utworów. Korzystanie użytkowe z utworów innych niż programy komputerowe dotyczy w szczególności utworów, których cechą może być współwystępowanie zarówno zewnętrznej, jak i wewnętrznej orientacji funkcjonalnej ${ }^{6}$. Określenia tu użyte wymagają ogólnego wyjaśnienia. Ujmując rzecz skrótowo, przez „orientację funkcjonalną” korzystania $\mathrm{z}$ utworów rozumiem sposób, w jaki w praktyce społecznej następuje typowe zaspokajanie potrzeb możliwych do zaspokojenia poprzez korzystanie z konkretnych dóbr intelektualnych. Analiza porównawcza przedmiotów prawa autorskiego oraz własności przemysłowej, przy zastosowaniu metody strukturalnej budowy utworów A. Kopffa ${ }^{7}$, prowadzi do wniosku, że istotnie występuje odmienność tak rozumianej orientacji funkcjonalnej tych różnych przedmiotów własności intelektualnej. Skutkuje to między innymi przyjęciem odmiennych rozwiązań w uregulowaniu prawa autorskiego i prawa własności przemysłowej. W przypadku przedmiotów prawa autorskiego zasadniczo użytkowość (w znaczeniu tu określonym) polega na wprowadzeniu informacji, jaką jest utwór do świadomości preceptora, co może być czasowo poprzedzone lub równoczesne z jego ustaleniem albo utrwaleniem $^{8}$. W przypadku projektów wynalazczych natomiast samo wprowadzenie do świadomości perceptora informacji będącej ich substratem nie prowadzi do zaspokajania typowych potrzeb, jakim służą. Zwykle wykorzystywane są one jako wzorzec do wytworzenia przedmiotu ukształtowanego lub nieukształtowanego, lub zastosowania metody, ewentualnie sposobu, zorientowanego funkcjonalnie

${ }^{6}$ Dotyczy to mojego, w chwili przygotowywania tego artykułu jeszcze nierozpowszechnionego opracowania pod tytułem 1) Utwory typograficzne... oraz 2) Utwory użytkowe - wybrane zagadnienia, które złożyłem do publikacji w wydawnictwie WPAiE Uniwersytetu Wrocławskiego w serii pod tytułem PPiA, planowane wydanie w 2020 roku.

7 Zob. A. Kopff, Dzieło sztuk plastycznych i jego twórca w świetle przepisów prawa autorskiego, Kraków 1961; idem, Dzieło i jego twórca, [w:] S. Grzybowski, A. Kopff, J. Serda, Zagadnienia prawa autorskiego, Warszawa 1973, s. $12 \mathrm{n}$.

8 Zob. J. Jezioro, Zarys systemu własności intelektualnej, [w:] R. Cisek, J. Jezioro, A. Wiebe, Dobra i ustugi informacyjne w obrocie gospodarczym, Warszawa 2005, s. 33 n. 
„zewnętrznie”. Najczęściej realizuje się to w działalności przemysłowej lub rzemieślniczej. Mają one służyć przekształceniu rzeczywistości przyrodniczej lub społecznej dzięki wykorzystaniu zasadniczo środków technicznych. Jak wskazano powyżej, odmienności te stały się podstawą do wprowadzenia odrębności w uregulowaniu przedmiotów prawa autorskiego oraz prawa własności przemysłowej.

Jednocześnie jednak można zaobserwować w praktyce obrotu, trzecią, bardziej złożoną sytuacją, którą określam jako „mieszana orientacja funkcjonalna”, cechuje się ona współwystępowaniem lub połączeniem w użytkowości obu orientacji - zarówno zewnętrznej, jak i wewnętrznej. Istotne problemy praktyczne w działalności gospodarczej wiążą się, jak oceniam, głównie z tą trzecią sytuacją. Nie zawsze są one właściwie postrzegane w szerszym kontekście konstrukcji prawnej i zapewne dlatego mogą stwarzać problemy w praktyce obrotu. Omawiana tu regulacja PrAut właśnie jej dotyczy, przy czym jest to jedynie element szerszego, stosunkowo zróżnicowanego uregulowania, którego postulatywnym celem jest rozwiązywanie konfliktów, jakie mogą wynikać w obrocie na tym tle. Poza wskazanym sygnalizacyjnie odrębnym uregulowaniem dotyczącym utworów użytkowych (w ścisłym tego słowa znaczeniu) może zdarzyć się, że konkretny przedmiot własności intelektualnej jest podstawą do wyodrębnienia niezależnie uregulowanych dóbr prawnych, na przykład dotyczy to wzorów przemysłowych (a więc projektów wynalazczych), które bardzo często pierwotnie mają cechy ustawowe utworów (zob. art. 102 i nast. PrWPrzem). Omawiane tu przepisy, choć zasadniczo dotyczą skutków zróżnicowania orientacji funkcjonalnej użytkowości przedmiotów własności intelektualnej, wprost nie regulują tych dwóch wskazanych sytuacji. Tworzą trzecią, odrębną grupę rozwiązań prawnych, będącą odbiciem odmiennej kategorii zdarzeń, występujących realnie w praktyce obrotu. Elementem wyróżniającym tę część uregulowania PrAut jest to, że objęte nimi przedmioty mogą $\mathrm{w}$ typowych sytuacjach, zaspokajać zarówno potrzeby możliwe do zaspokojenia przez docelowego ich odbiorcę (orientacja funkcjonalna wewnętrzna), jak i być wykorzystywane w działalności produkcyjnej — a żadna $z$ tych orientacji nie dominuje ich charakteru. To skonkretyzowana praktyka (wybory dokonywane przez przedsiębiorców i innych uczestników obrotu) decyduje, która $\mathrm{z}$ tych orientacji funkcjonalnych jest realizowana; dlatego też ustawodawca przyjął odmienną metodę uregulowania, która nie kreuje wprost lub pośrednio odrębnego dobra prawnego (na przykład utworu użytkowego, za jaki można uznać program komputerowy), ale dotyczy rzeczywistego sposobu korzystania z dowolnego dobra, a więc jego okoliczności (na przykład stworzenia utworu w ramach wykonania obowiązków ze stosunku pracy).

W omawianym tu przypadku utworów pracowniczych ustawodawca, poza programami komputerowymi, nie zdecydował się na ograniczenie ochrony interesów osobistych twórcy w przypadku utworów pracowniczych tylko do autorstwa, ale powiązał je $\mathrm{z}$ autorem-pracownikiem w sposób niezbywalny i nieograniczony 
czasowo. Odnośnie do praktyki obrotu oznaczać to może konieczność umownego zapewnienia sobie przez pracodawcę ingerencji w sferę dóbr osobistych autora. Skoro więc ustawowo bezwzględnie wyłączona została możliwość rozporządzenia autorskimi prawami osobistymi, to pozostaje jedynie możliwość uzyskania upoważnienia do ingerencji w interesy objęte tą ochroną lub dalej idące upoważnienie do wykonywania tych uprawnień, poprzez odpowiednią redakcję umowy o pracę. Całościowe omówienie ewentualnych, standardowych klauzul umownych w tym opracowaniu jest niemożliwe; można jednak wskazać na ogólne zasady, którymi przy ich formułowaniu należy kierować ${ }^{9}$. Klauzule takie, ze względu na rodzaj dóbr, których dotyczą, nie powinny mieć charakteru „blankietowego”. Wydaje się, że z ich treści powinny wynikać co najmniej okoliczności oraz zakres ingerencji w autorskie prawa osobiste; przy czym nie musi to przybierać postaci ściśle skonkretyzowanej. W przypadku przedsiębiorców za akceptowalny miernik zakresu i okoliczności ingerencji należy uznać prawnie dopuszczalny cel prowadzonej przez nie działalności gospodarczej, wynikający przykładowo z zadań określonych statutowo. Za dopuszczalne uznaje się także wprowadzenie odpowiedzialności odszkodowawczej kontraktowej (na przykład w postaci kar umownych), na wypadek cofnięcia przez autora zgody na określone korzystanie, ingerujące w dobra osobiste. Ponadto przy konstruowaniu stosownych klauzul należy wziąć pod uwagę, że w pewnym zakresie ustawodawca, w ramach instytucji dozwolonego użytku oraz przepisów dotyczących stosunków umownych dopuścił pewne postaci ingerencji $\mathrm{w}$ dobra osobiste przy korzystaniu $\mathrm{z}$ utworów, a tym samym, w tym zakresie, umownie celowe jest jedynie skonkretyzowanie, stosownie do okoliczności tych zasad. Przykładowo w zakresie prawa do autorstwa, zgodnie z art. 34 PrAut, podanie twórcy i źródła powinno uwzględniać istniejące możliwości; natomiast zgodnie $\mathrm{z}$ art. 49 PrAut, jeżeli w umowie nie określono sposobu korzystania z utworu, powinien on być zgodny z charakterem i przeznaczeniem utworu oraz przyjętymi zwyczajami (ust. 1). Przepis art. 49 ust. 2 PrAut dopuszcza też możliwość zmian w utworze, jeżeli są one spowodowane oczywistą koniecznością, a twórca nie miałby słusznej podstawy im się sprzeciwić.

Kolejną kwestią wymagającą zasygnalizowania jest zakres nabywanych przez pracodawcę uprawnień majątkowych, składających się na autorskie prawa majątkowe, a zwłaszcza zakres pól eksploatacji objętych takim nabyciem. Przyjmuje się, że ustawodawca nie wykluczył możliwości nabycia ogółu takich uprawnień, ale uzależnił to od wprowadzenia do umowy stosownej klauzuli. W jej braku zastosowanie znajdzie dość ogólna klauzula interpretacyjna „celu umowy o pracę” (zob. art. 12 ust. 1 in fine PrAut). Także w tym zakresie, z punktu widzenia interesów przedsiębiorców, postulatywnie zasady wynikające $\mathrm{z}$ ustawy wymagają dookreślenia przez wprowadzenie do umowy o pracę dodatkowych klauzul. Zgodnie

9 Zob. propozycje klauzul umownych z komentarzem J. Barta, R. Markiewicz, Prawo autorskie, Warszawa 2016, s. 362. 
z dyspozytywnym art. 12 ust. 3 PrAut wraz z prawami autorskimi na pracodawcę zasadniczo przechodzi własność przedmiotu, na którym utrwalono; przy czym ustawa nie rozstrzyga kwestii zasad rozliczenia kosztów z tym związanych — stąd w niektórych sytuacjach, z punktu widzenia interesów przedsiębiorców, w praktyce będzie to wymagało dookreślenia w umowie o pracę.

Omawiana tu regulacja szczególna dotyczy także utworów pracowniczych, które na podstawie umowy przeznaczone są do rozpowszechniania. Jak z tego wynika, powstanie objętych uregulowaniem PrAut sytuacji wymaga istnienia wyraźnych postanowień $\mathrm{w}$ umowie o pracę w tej kwestii, a uregulowanie art. 12 ust. 3 „wpisuje się" w szerszą zasadę (zob. też art. 14 ust. 1, 15a ust. 1 oraz 72 PrAut), która zdaje się przeciwdziałać swoistemu ,blokowaniu” — tu przez pracodawców rozpowszechnienia takich utworów. Zgodnie z art. 12 ust. 2 PrAut uprawniony pracodawca może utracić prawa do utworu wraz z prawem własności jego nośnika materialnego, jeśli w terminie dwóch lat (termin ten może być umownie zmieniony) od daty przyjęcia utworu nie przystąpi do jego rozpowszechnienia. Dodatkowym warunkiem wystąpienia tego skutku jest wyznaczenie na piśmie przez pracownika odpowiedniego terminu na przystąpienie do rozpowszechniania konkretnego utworu z zagrożeniem wystąpienia wskazanego wcześniej skutku, na wypadek bezskuteczności tego wezwania.

Ostatni, szczegółowo uregulowany w PrAut rodzaj utworów pracowniczych można określić jako ,pracownicze utwory naukowe”; przy czym poza uregulowaniem PrAut, i to w szerszym zakresie, zastosowanie do utworów akademickich znajdą także przepisy ustawy z 20 lipca 2018 roku Prawo o szkolnictwie wyższym i nauce ${ }^{10}$. W tej kwestii można jedynie wskazać, że ustawa ta nakłada na poszczególne uczelnie obowiązek stosowania regulaminów zarządzania prawami autorskimi i prawami pokrewnymi oraz prawami własności przemysłowej oraz zasadami komercjalizacji. W praktyce gospodarczej te regulaminy będą miały zasadnicze znaczenie dla kształtu relacji z tak zwanym otoczeniem gospodarczym. Zgodnie z ustawą regulaminy takie określają między innymi zasady i procedury komercjalizacji akademickich przedmiotów własności intelektualnej. Z art. 14 PrAut wynika natomiast jedynie, że instytucja naukowa, jeśli jej pracownik w wykonywaniu obowiązków ze stosunku pracy stworzy utwór naukowy, ma ograniczone czasowo prawo do pierwszeństwa jego publikacji; traci to prawo, jeżeli w ciągu sześciu miesięcy od dostarczenia utworu nie nastąpi zawarcie umowy z twórcą o wydanie dzieła albo jeżeli w ciągu dwóch lat od daty przyjęcia utworu nie nastąpi jego publikacja. Autorowi przysługuje w takich przypadkach prawo do wynagrodzenia. Instytucja taka może, bez odrębnego wynagrodzenia, korzystać z materiału naukowego, zawartego w utworze oraz udostępniać ten utwór osobom trzecim, jeżeli to wynika z uzgodnionego przeznaczenia utworu lub zostało postanowione w umowie.

10 Tekst jedn. Dz.U. z 2020 r. poz. 85. 
Specyficznym, pośrednio związanym z regulacją pracowniczych utworów naukowych uregulowaniem jest przepis art. 15a PrAut, dotyczący uprawnień uczelni oraz ministra właściwego do spraw szkolnictwa wyższego i nauki w stosunku do prac dyplomowych studentów. Uczelni takiej na tej podstawie przysługuje pierwszeństwo w opublikowaniu pracy dyplomowej studenta, a jeżeli uczelnia nie opublikowała pracy dyplomowej w ciągu sześciu miesięcy od jej obrony, student, który ją przygotował, może ją opublikować, chyba że praca dyplomowa jest częścią utworu zbiorowego. Ponadto uczelnie oraz wskazany powyżej minister mają prawo korzystać z prac dyplomowych, w związku z wdrożeniem Jednolitego Systemu Antyplagiatowego. W pozostałym sytuacja prac dyplomowych wynika z zasad ogólnych — nie stosuje się, choćby odpowiednio, przepisów dotyczących utworów pracowniczych. Podstawowe znaczenie mają umowy zawarte przez uczelnie ze studentami, z uwzględnieniem zasad określonych przez przepisy PoSWiN.

\section{Utwory zbiorowe oraz utwory będące zbiorami}

Ze względu na specyficzny sposób powstawania utworów za użytkowe korzystanie z nich należy uznać korzystanie uregulowane w art. 3 i 11 PrAut. W obu przypadkach ma to prowadzić do powstania nowego „rodzaju” utworu, zdefiniowanego literalnie przez ustawodawcę jedynie przez przykłady. Odpowiednio, przykładem zbioru utworów są antologie, wybory, bazy danych, a utworów zbiorowych w ujęciu ustawowym - periodyki, słowniki i encyklopedie. Katalog ten ma charakter otwarty i — jak oceniam — ustawodawca posłużył się nim, aby zdefiniować nie odrębny rodzaj utworów, ale pewien sposób korzystania z utworów, który prowadzi do powstania odrębnych dóbr prawnych jako efektu takiego korzystania, a określenia ustawowe zdają się ku temu zmierzać. Tak więc odpowiednio - autor zbioru oraz wydawca i producent wykorzystują utwory, których zasadniczo sami nie tworzą (nie jest to jednak warunek konieczny), ale używają ich jako elementu odrębnego dobra prawnego, poprzez włączenie ich do zbioru lub stosowne wykorzystanie przy tworzeniu utworu zbiorowego, co, zgodnie z koncepcją uży tkowej orientacji funkcjonalnej, oznacza korzystanie o orientacji ukierunkowanej przede wszystkim zewnętrznie, a więc wykraczającej poza li tylko wprowadzenie substratu konkretnego utworu w postaci przekazu informacyjnego do świadomości korzystającego. Ma to prowadzić do powstania nowego dobra (w tym przypadku utworu, na przykład antologii lub encyklopedii), które to dobro ma dopiero w dalszej kolejności być przedmiotem korzystania „konsumpcyjnego” (o orientacji kierunkowej wewnętrznej). W efekcie dla twórcy takiego utworu polega to na korzystaniu o orientacji zewnętrznej. $Z$ tego powodu omawiane tu uregulowanie ma wyraźnie uzasadnienie w użytkowym korzystaniu z utworów; natomiast obu omawianych „rodzajów” utworów podobnie jak w przypadku utworów pracowniczych nie można uznać za utwory użytkowe w ścisłym znaczeniu, 
tak jak to jest z programami komputerowymi, ponieważ efekt tego korzystania w postaci skonkretyzowanego utworu, będącego zbiorem, lub utworu zbiorowego przybiera postać utworu o użyteczności zasadniczo zorientowanej wewnętrznie.

Podstawowym problemem rozstrzyganym przez ustawodawcę w analizowanych tu przepisach są relacje pomiędzy podmiotem uprawnionym do tych utworów a podmiotami uprawnionymi do wykorzystanych przez niego utworów oraz charakter prawny efektu takiego korzystania. Przedmiotem takich działań moga być dowolne rodzaje utworów, a więc podobnie jak w przypadku utworów pracowniczych mamy tu do czynienia z bardzo zróżnicowanymi sytuacjami. Co więcej, w praktyce obrotu sytuacja może być jeszcze bardziej prawnie złożona, jeśli poza utworami wykorzystywane są w ten sposób innego rodzaju dobra prawne (na przykład dane osobowe, wizerunek itp.). Istotne jest, że kwestie legalizacji takiego korzystania są uregulowane odrębnie — poza PrAut — a w tym miejscu możliwe jest jedynie zasygnalizowanie tego problemu.

Ogólnie podstawowa różnica pomiędzy tymi sytuacjami (korzystaniem uregulowanym w art. 3 i 11 PrAut) wynika z faktu istnienia (w chwili ich tworzenia) wykorzystywanych poprzez włączenie do zbioru różnego rodzaju utworów (tak jest w przypadku zbioru) lub potrzeby ich stworzenia w celu wykorzystania w utworze zbiorowym. Przy czym w tym ostatnim przypadku stwarza to możliwość wpływu na powstające utwory, które tworzone są „na zamówienie” wydawcy lub producenta.

W płaszczyźnie prawnej różnice są bardzo wyraźne. Zbiór, jeśli przyjęty w nim dobór, układ lub zestawienie mają charakter twórczy, prowadzi do powstania w pełnym zakresie (a więc zarówno majątkowych, jak i osobistych) praw autorskich na rzecz jego twórcy. Skutek powstania utworu zbiorowego zbliża się natomiast bardziej do skutków powstania utworów pracowniczych — jego wydawca lub producent nabywa jedynie autorskie prawa majątkowe wraz z prawem do tytułu (w tym zakresie nabycie objęte jest jednak wzruszalnym domniemaniem), a do poszczególnych części, mających samodzielne znaczenie, „,ównolegle”, prawa autorskie majątkowe i osobiste powstają na rzecz ich twórców. Tak więc nie następuje tu przejście na podstawie ustawy praw do utworów, ale pojawia się nowe dobro w postaci utworu zbiorowego, którego elementem są utwory tworzone na zamówienie wydawcy lub producenta. W efekcie powstanie utworu zbiorowego jest swoistym ekwiwalentem nie za wkład twórczy, ale za poniesiony nakład inwestycyjny — zwykle polegający na wniesieniu wartości ekonomicznej, koncepcyjnej oraz organizacyjnej. Do tego dostawany jest instrument prawny, chroniacy interesy wydawcy lub producenta — nie powstają na jego rzecz autorskie prawa osobiste.

Nietrudno zauważyć, że w przypadku utworów zbiorowych ustawodawca czyni wyraźny wyjątek od zasady, że podstawą wyodrębnienia utworu jako dobra prawnego jest przesłanka indywidualnej twórczości. Wkład wydawcy lub produ- 
centa, inaczej niż osoby lub osób tworzących zbiór, którego dotyczy art. 3 PrAut, nie musi mieć tej cechy. Tym bardziej nasuwa się ocena, że przepis art. 11 PrAut reguluje przede wszystkim pewną postać użytkowego korzystania z utworów, a przyjęta przez ustawodawcę konstrukcja wyznaczona jest przez zewnętrznie ukierunkowaną orientację funkcjonalną takiego korzystania. Przy czym jest to sytuacja odmienna, bardziej złożona od uregulowanej w przepisach dotyczących utworów pracowniczych; stąd też przepisy te nie wykluczają się, ale uzupełniają, kiedy równocześnie spełnione zostaną przesłanki z art. 12 PrAut.

$\mathrm{Na}$ koniec należy odnieść się do istotnych kwestii praktycznych, związanych bezpośrednio $\mathrm{z}$ działalnością przedsiębiorców (w tym wydawców i producentów utworów zbiorowych). Omówiony tu stan uregulowania, powstanie z mocy ustawy praw autorskich na rzecz autorów oraz wydawców i producentów, nie zwalnia podmiotów korzystających z cudzej twórczości jako elementów utworów będących zbiorami oraz utworów zbiorowych z legalizacji takiego korzystania. W przypadku utworów zbiorowych podstawą legalizacji korzystania mogą być zarówno czynności rozporządzające (na przykład nabycie autorskich praw majątkowych na podstawie umowy sprzedaży), jak i uzyskanie upoważnienia do korzystania w postaci licencji (zob. art. 65-68 PrAut). Podobnie jak w przypadku utworów pracowniczych, w odniesieniu do uprawnień osobistych, możliwe jest jedynie uzyskanie uprawnień względnych, na zasadach wyżej omówionych. Analogiczne zasady dotyczą utworu będącego zbiorem z tym jednak, że legalizacja korzystania może być w praktyce prostsza i mieć węższy zakres, jeśli korzystanie dotyczy utworów, których okres ochrony już upłynął (zob. art. 36 i nast. PrAut) lub sposób ich wykorzystania mieści się w granicach dozwolonego użytku (zob. art. 23 i nast. PrAut). Jak już to zasugerowano, wymóg legalizacji wykorzystania dotyczy odpowiednio innego rodzaju dóbr prawnie chronionych, włączonych do takiego zbioru (na przykład wizerunku, danych osobowych itp.).

\section{Bibliografia}

Barta J., Markiewicz R., Prawo autorskie, Warszawa 2016.

Jezioro J., Sposób wyrażenia utworu architektonicznego jako element prawnego wyodrębnienia tego rodzaju utworów, [w:] Wybrane zagadnienia polskiego prawa prywatnego: księga pamiatkowa ku czci Doktora Józefa Kremisa i Doktora Jerzego Strzebinczyka, red. J. Jezioro, K. Zagrobelny, Wrocław 2019.

Jezioro J., Utwór jako element przedmiotu świadczenia w umowach o tzw. „świadczenia edukacyjne", [w:] Ius est ars boni et aequi: księga pamiątkowa dedykowana Profesorowi Józefowi Frackowiakowi, red. A. Dańko-Roesler et. al., Warszawa 2018.

Jezioro J., Zarys systemu własności intelektualnej, [w:] R. Cisek, J. Jezioro, A. Wiebe, Dobra i ustugi informacyjne w obrocie gospodarczym, Warszawa 2005.

Kopff A., Dzieło i jego twórca, [w:] S. Grzybowski, A. Kopff, J. Serda, Zagadnienia prawa autorskiego, Warszawa 1973.

Kopff A., Dzieło sztuk plastycznych i jego twórca w świetle przepisów prawa autorskiego, Kraków 1961. 
Ustawa z dnia 4 lutego 1994 roku o prawie autorskim i prawach pokrewnych, tekst jedn. Dz.U. z 2019 r. poz. 1231 ze zm.

Ustawa z dnia 30 czerwca 2000 roku Prawo własności przemysłowej, tekst jedn. Dz.U. z 2020 r. poz. 276.

Ustawa z dnia 20 lipca 2018 roku Prawo o szkolnictwie wyższym i nauce, tekst jedn. Dz.U. z 2020 r. poz. 85 .

Wyrok SA w Poznaniu z dnia 20 lutego 2009 roku (I ACa 87/08, niepubl.). 